\title{
Japan's Role in Asia-Pacific Cooperation: Dimensions, Prospects, and Problems
}

\author{
Edward J. Lincoln
}

Working Paper No. 41

Edward J. Lincoln

Senior Fellow

The Brookings Institution

Prepared for the study on economic cooperation in the Asia-Pacific Region sponsored by the American Council on Asian and Pacific Affairs.

Working Paper Series

Center on Japanese Economy and Business

Graduate School of Business

Columbia University January 1990 


\section{Introduction}

Japan's relationship with the world and especially with the Asia-Pacific region is changing rapidly. These shifts hold both promise for closer and more productive interactions as well as concerns over the possible exclusive nature of the evolving relationships. The cause of the changes come from the macroeconomic developments considered in Dick Nanto's paper-developments that have produced large net capital outflows and a strong appreciation of the yen. The purpose of this paper is to explore Japan's position in the development of trade and investment ties in the Asia-Pacific region, review the changes now taking place in Japan's relationship toward these countries, and provide some speculation on future developments.

Economic ties among Asia-Pacific nations have increased over time, although most of the increase is due to larger flows between these countries and the United States and Japan. Even without these two, however, a gradual strengthening of trade ties has taken place. Japan and the United States have had trade and investment roles of roughly equal importance toward the rest of the region, but the changes now taking place will bring Japan closer while diminishing the position of the United States. As this shift unfolds, there is some concern that Japan's stronger relationship with the region will take an exclusive form, pulling other Asian nations closer to it while progressively excluding the United States and other non-Asian nations. Such moves would not be in the interest of the United States, and could be economically and politically harmful throughout the region. This paper concludes that cooperation in the region should not, therefore, take the form of any formal regional trade preference arrangement. Furthermore, while a new formal regional organization which would bring together government officials to discuss matters of mutual interest make sense given 
the rising regional economic ties, most economic issues are properly discussed in a global setting rather than a regional one.

\section{Background}

The countries of the Asia Pacific region have little in common other than geography. The United States is generally assumed to belong to the region, but it is not tied to Asia by any strong cultural features. Even within Asia, the cultural and religious differences among nations are quite large, although some common cultural traits characterize all or most of these countries. Furthermore, the economic differences are enormous, ranging from Japan and the United States as advanced industrial nations with very high per capita incomes, to China and the Indochina countries close to the bottom of world incomes and development. This region, therefore, is very different from Europe where common land borders and strong cultural and historical connections have driven a process of integration. In the AsiaPacific area geography remains the main reason for closer economic ties.

Economic relations among these countries can be considered in a number of ways. The discussion here concentrates on three of these: merchandise trade, direct investment flows, and foreign aid. Connections among these individual ties certainly exists, especially in the case of Japan, but it is convenient to begin by considering them separately.

Merchandise Trade--Data on intra-regional trade is presented in Table 1 , based on the detailed trade matrix presented in Table 2. For all the nations on the list, the share of exports destined to other nations in the region was almost one half ( 48 percent) in 1986. This represents a very large gain of 27 percentage points since 1966. The only nations included in the table that are clearly not part of the region in terms of trade are 
TABLE 1

Regional Exports

Country Fercent of its exports destined

Fercent of its exports

to the rest af the region

destined to the subregion
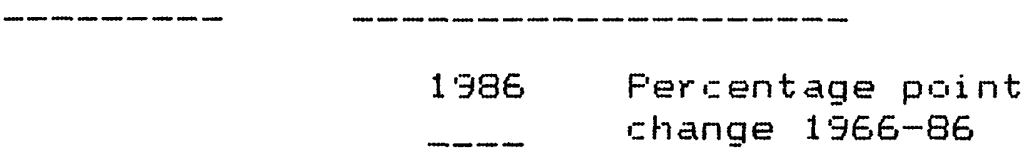

1986

Fercentage point

- change $1 \overline{9} 66-86$

United States
Japan
Canada
USSF
Ehina
South Korea
Taiwan
Hong Fong
Singapore
Fhilippines
Thailand
Indonesia
Malaysia
Australia
New Zealand
Total Fegion
Subregion

$2 \epsilon$

68

8

10

$\epsilon \in$

68

78

72

68

76

62

85

73

68

$E 1$

48

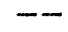

11

7

0

$-1$

14

$-8$

10

13

17

$-2$

$E$

23

15

16

27

20

$-$
14

27

4

4

42

11

15

33

36

21

28

20

34

29

29

$\epsilon$

$-1$

1

4

10

1

$-2$

10

9

16

1

2

24

24

21

$--$

24

Note: The subregion excludes the United States, Japan, Canada, and the Soviet Union.

Source: Calculated from the data in Table 2, which is taken from the International Monetary Fund, Direction of Trade Annual. 
Canada and the Soviet Union, and they are excluded from the discussion in the remainder of this paper.

Much of the regional trade is accounted for by the United States and Japan, and the very rapid growth of the Japanese economy could account for a large portion of the above results. Therefore, Table 1 also shows trade for a subset of the region--the list of countries in Table 1 minus Japan, the United States, Canada and the Soviet Union. As might be expected, the share of exports going to others within the subset is much lower ( 24 percent in 1986), and the growth over time is generally lower as well (up 9 percentage points from 15 percent in 1966). Nevertheless, it is significant that this share is increasing. The rise is especially noticeable for the three former British colonies--Australia, New Zealand and Malaysia. Over the 20 year period in the table, these three lost much of their attachment to the British commonwealth countries and became much more integrated with Asia, including both the entire group of countries in the table and the subregion.

As evident from Table 2, the nature of relationships between individual countries on this list and the major markets of Japan and the United States is diverse. In 1986, the countries in the subset sent 24 percent of their exports to the United States (a substantial gain from 14 percent in 1966), while only 14 percent went to Japan (down three percentage points over the same period). The downward shift for Japan is due primarily to the diversification of trade by Taiwan and South Korea, both of which were colonies before the war and remained highly dependent on Japan as an export market for a time after the war.

In addition to the fact that a larger share of exports has gone to the United States, there is a qualitative difference in trade with the United 


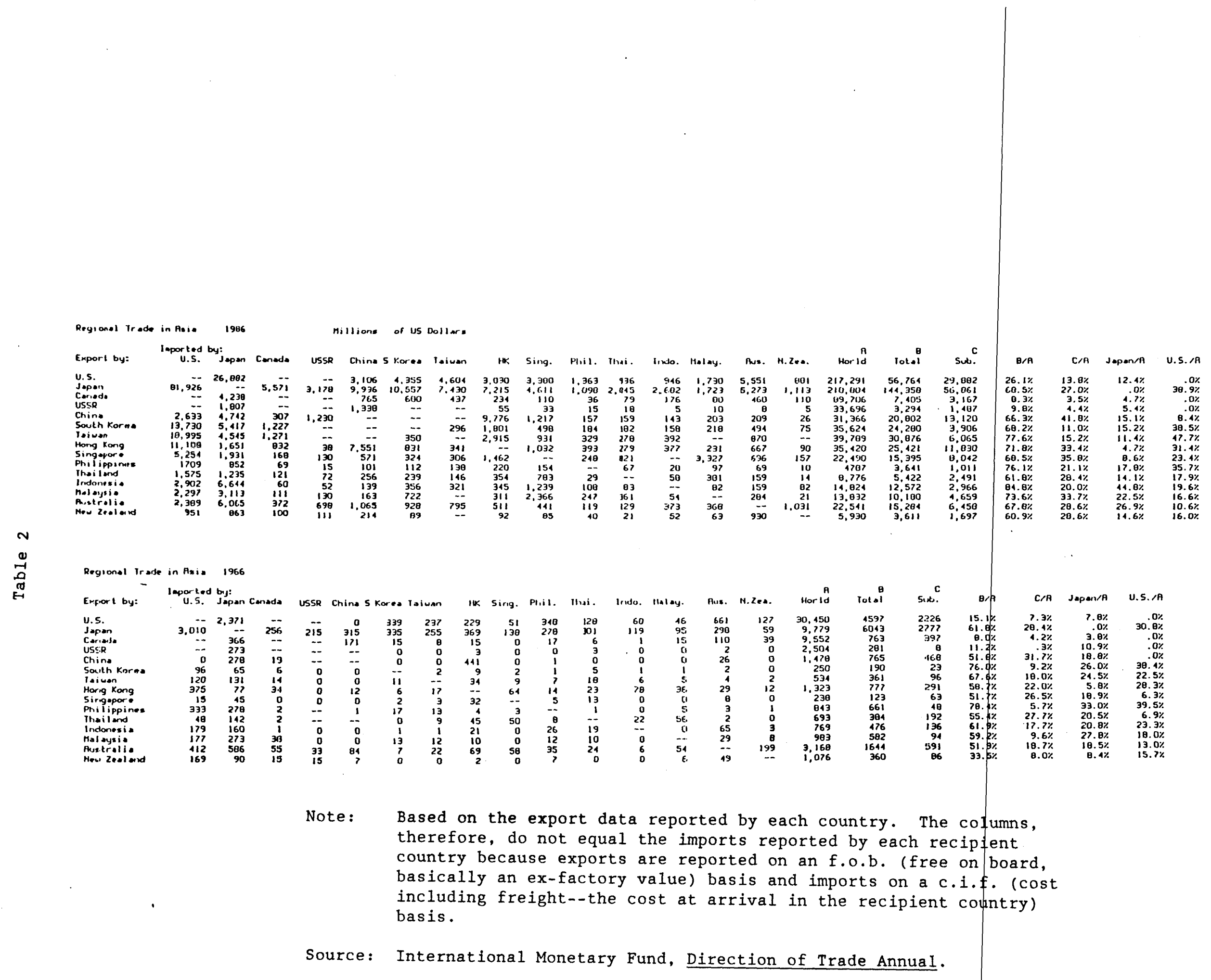


States and with Japan. Those few countries with a substantial share of their exports destined to Japan are mostly raw material exporting countries: Australia (coal and iron ore), Malaysia (tin), and Indonesia (oil and gas). Japan has had a reputation in the past for not welcoming manufactured imports from the world or from Asia. Indicative of Japan's reluctance to import manufactures, the ratio of manufactured imports to GDP remains considerably below that of other industrial nations. ${ }^{1}$ Furthermore, the bulk of the increase in Asian exports in the first half of the 1980 was to the United States. Japan's imports from the rest of Asia stagnated (and in some cases dropped because of falling raw material prices).

On the import side (Table 3 ), similar relationships are visible, although the relative roles of Japan and the United States are reversed. For individual countries, the importance of the region or the subregion as a source of imports is largely the same as the export picture. However, the share of imports in these countries sourced from Japan was 24 percent in 1986 (up substantially over 1966, while the share from the United States was a smaller 19 percent (virtually unchanged since 1966). The only Asian countries importing more from the United States than from Japan are the Philippines (with strong historical ties to the United States) and Australia. For a number of others, Japan has a far greater share of imports than does the United States, including China, Hong Kong, Indonesia, and Thailand.

These data on exports and imports indicate that Japan and the United States are the major trading partners for these countries. But in no sense

1. Japan's relative lack of manufactured imports is discussed in detail in Edward J. Lincoln, Japan's Unequal Trade (Washington: The Brookings Institution, forthcoming). 
TABLE 3

IMPORTS FROM THE REGION

$$
\begin{aligned}
& \text { share of imports of each country coming from: } \\
& \text { U.S. Japan region subregion }
\end{aligned}
$$

$\begin{array}{lrrrr}\text { United States } & .0 \% & 20.8 \% & 51.4 \% & 13.7 \% \\ \text { Japan } & 7.9 \% & .0 \% & 43.3 \% & 29.8 \% \\ \text { Canada } & 64.8 \% & 6.3 \% & 75.7 \% & 4.5 \% \\ \text { USSR } & 3.6 \% & 6.3 \% & 17.0 \% & 5.5 \% \\ \text { China } & 11.2 \% & 23.3 \% & 68.6 \% & 27.8 \% \\ \text { South korea } & 21.4 \% & 33.3 \% & 70.2 \% & 13.3 \% \\ \text { Taiwan } & & & & \\ \text { Hong Kong } & 8.5 \% & 19.0 \% & 72.5 \% & 44.1 \% \\ \text { Indonesia } & 9.4 \% & 33.4 \% & 65.6 \% & 20.4 \% \\ \text { Malaysia } & 18.7 \% & 21.7 \% & 75.0 \% & 33.5 \% \\ \text { Philippines } & 22.2 \% & 16.5 \% & 63.5 \% & 23.2 \% \\ \text { Singapore } & 14.7 \% & 20.5 \% & 68.7 \% & 32.9 \% \\ \text { Thailand } & 12.5 \% & 26.0 \% & 63.4 \% & 23.5 \% \\ \text { Australia } & 21.4 \% & 19.7 \% & 59.4 \% & 16.2 \% \\ \text { New Zealand } & 15.6 \% & 18.7 \% & 64.1 \% & 27.8 \% \\ & & & & \\ \text { Total regian } & 11.4 \% & 16.1 \% & 55.1 \% & 18.5 \% \\ \text { subregion } & 14.8 \% & 23.5 \% & 68.3 \% & 27.6 \%\end{array}$

Source: Calculated from data in International Monetary Fund, Direction of Trade Annual, 1381-1987. 
has Japan "replaced" the United States within the region. The United States has not lost share as either a destination for the exports of these countries nor as a source of their imports. On the import side, Japan's gain as a source of the region's imports has come at the expense of countries other than the United States. A better characterization would be to say that both Japan and the United States have come to dominate the trade of these nations to a greater degree than in the past. Nevertheless, the high share of Japan in the imports of these countries, and the growth of that share is a significant long-term development.

Direct Investment--Investment patterns appear roughly similar to trade. Table 4 presents basic data on direct investment. In the Asian NICs, the United States has generally had higher levels of cumulative investment (except in South Korea), while in the ASEAN countries, Japan has had the larger share (except for the Philippines). Only in Malaysia are neither Japan nor the United States the largest single foreign investor (with that position held by Singapore).

Much of Japanese foreign direct investment has been destined toward Asia, but over time a smaller share of investment has gone to Asia as the horizons of Japanese investors have expanded. A large share of Japan's direct investment in Asia in the past has also gone to resource development projects, dominated by Indonesia. Manufacturing investment in developing countries in Asia has not been a large part of Japanese investment activity in the past, and the manufacturing investment that did take place was motivated more by the desire to supply products to local markets or to third markets (especially the United States). An attempt to circumvent import protectionism in these countries or in the United States provided a stronger rationale for manufacturing investment than did the existence of low wages. 
TABLE 4

Cumulative Foreign Direct Investment in Selected Asian Countries

\begin{tabular}{|c|c|c|c|c|c|c|}
\hline $\begin{array}{l}\text { Fecipient } \\
\text { Eountry }\end{array}$ & $\begin{array}{l}\text { Share of } \\
\text { Japan }\end{array}$ & $\begin{array}{c}\text { Investment } \\
\text { U.S. }\end{array}$ & $\begin{array}{l}\text { From: } \\
\text { FOOW }\end{array}$ & Tatal & $\begin{array}{l}\text { Inward } \\
\text { FDI }\end{array}$ & Date \\
\hline$-\cdots-\cdots--$ & --- & $-\cdots-\cdots$ & ---- & & -1 & $-\cdots-$ \\
\hline Hong Kong & $2 \%$ & $54 \%$ & $24 \%$ & & $\$ 1.5$ & $9 / 84$ \\
\hline South Korrea & 48 & 30 & 22 & & 2 & $6 / 84$ \\
\hline Taiwan & 30 & 42 & 29 & & 3.3 & $12 / 84$ \\
\hline Singapore & 20 & 33 & 47 & & 5 & $6 / 83$ \\
\hline Thail and & 23 & 9 & $E 8$ & & 7 & $12 / 83$ \\
\hline Indonesia & 35 & 8 & 58 & & 14.4 & $12 / 83$ \\
\hline Mal aysia & 18 & 7 & 75 & & 3.4 & $12 / 83$ \\
\hline Fhilippines & 16 & 52 & 32 & & 2.5 & $12 / 83$ \\
\hline
\end{tabular}

Source: Bank of Japan, Monthly Feport of Fesearch Department, January 1986, aited in Yasuhiko Tori i, "Fecent Trend and Fole of Japan in Financing Growth of Asian Countries." 
Japanese industry has had a generally strong belief that it could manufacture products of higher quality and with competitive prices from a Japanese production base even as the relative cost of labor rose steadily through the 1960s and 1970s. Japanese innovations in manufacturing processes, including methods of reducing inventory costs (such as just-intime production) and reducing product defect rates were assumed to be dependent on a concentration of the manufacturing process geographically, and on the special nature of human relationships in the Japanese culture. Japanese firms generally sought to reduce labor costs through automation rather than by moving abroad.

With these perceptions of the advantages of Japanese manufacturing technology, investments abroad have tended to have an unusually high number of Japanese nationals in the management structure. ${ }^{2}$ In addition, some countries, especially China, have been complaining for some time over the relative lack of technology transfer to these subsidiaries.

Foreign Aid--Unlike trade and direct investment, Japan is the dominant source of ODA for Asian developing countries. The total amount of ODA from Japan now rivals that of the United States (with the Japanese expecting that in 1989 they may actually surpass the United States), and the dollar amount continues to grow at a fairly rapid pace. According to OECD data, total Japanese ODA has been growing at a 5.7 percent annual average rate from 1982 to 1987 , while that of the United States has grown at only a 2.2 percent rate. ${ }^{3}$ of Japanese ODA disbursed bilaterally, the majority continues to go

2. Nihei, Ohtsu, and Levin, "A Comparative Study of Management Practices and Workers in an American and Japanese Firm in Hong Kong," in Hong and Levin, eds., Contemporary Issues in Hong Kong Labour Relations (Hong Kong: University of Hong Kong, 1983).

3. Organization for Economic Cooperation and Development, Development Cooperation, 1988 Report (Paris, OECD 1988), p. 172. 
to Asia, even though that portion has declined somewhat over time as Japan has added other, non-Asian countries to the list of recipients. As of 1986 , the share of Japan's bilateral aid destined to Asia (broadly defined to include South Asia) was 73 percent. 4

Figure 1 shows for the ASEAN countries the share of Japan, the United States, and the multilateral aid agencies in net total ODA receipts. Net receipts represent actual new disbursements minus repayment of concessional loans, and thereby represents a more accurate figure on actual foreign aid activity than does commitments. Two striking facts are evident from these data: Japan provides half or more of the ODA received by each of the ASEAN countries (far outdistancing funds from the multilateral agencies), and the United States provides virtually nothing except to the Philippines. For ASEAN as a whole, Japan provided 55 percent of net ODA in 1987, with the United States accounting for only 11 percent, and the multilateral organizations only 10 percent.

The dollar amounts of the ODA flows to Asian countries is displayed in Table 5. Other than the Philippines, American ODA to ASEAN is pitifully small: none to Malaysia, $\$ 36$ million to Indonesia, $\$ 23$ million to Thailand and $\$ 1$ million to Singapore. Except for Singapore, Japan's ODA is measured in hundreds of millions of dollars, and it outspends the United States even in the Philippines. Furthermore, the top recipient of Japanese aid for the past several years has been China (with net receipts from Japan in 1987 of $\$ 553$ million), a country to which the United States provides nothing.

The incident in Tienanmen Square in the spring of 1989 put a temporary hold on Japanese aid to China, but there was every indication that the hold

4. Ibid., p. 178 . 
FIGURE 1

Shares of Net ODA Flow, 1987

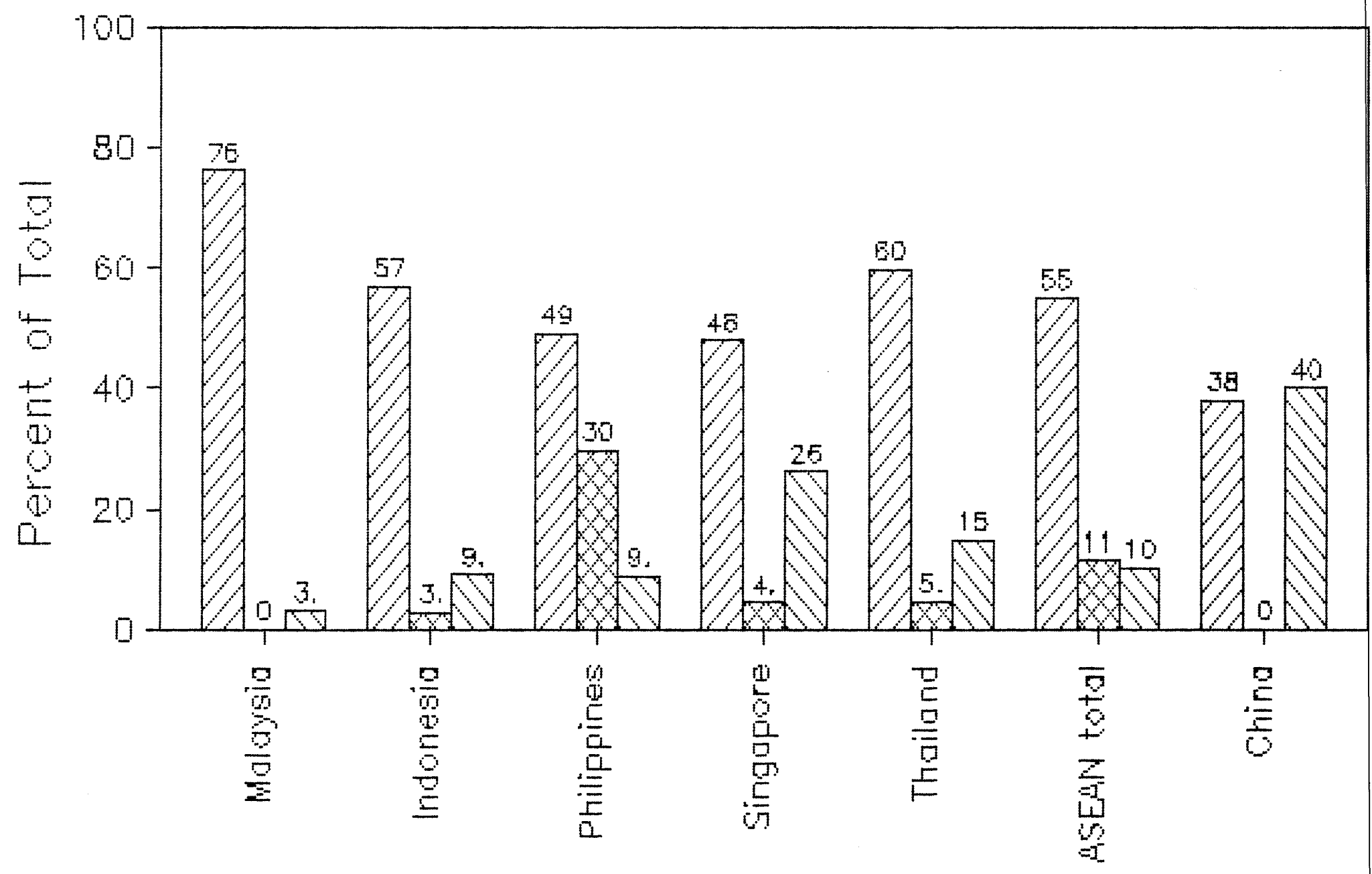

E/ Japan

89 u.

Multilateral

Country 
TABLE 5

Net ODA Feceived by Southeast Asian Countries, 1987

(amounts in millians of dollars)

Country Total ODA net receipts

Bilateral net ODA from: Japan U.S.

Malaysia

Indonesia

Fhilippines

Singapore

Thail and

ASEAN total

Dhina

Burma

Kampuinea

Lags

Vietnam

$$
\begin{array}{r}
\$ 363 \\
1,245 \\
775 \\
23 \\
506
\end{array}
$$

$\$ 2,549$

1,449

$\$ 364$

14

59

116
$\$ 276$

707

379

11

302

$\$ 1,399$

$\$ 553$

$\$ 172$

0

14

1

$\$ 0$
36
230
1
23

$\$ 290$

\$o

$\$ 11$

2

0

1
Net DDA from mul ti lateral agencies

$$
\begin{array}{r}
\$ 11 \\
112 \\
69 \\
6 \\
75
\end{array}
$$

$\$ 262$

$\$ 588$

$\$ 124$

5

28

51

Source: OECD, Geographical Distribution of Financial Flows to Developing Countries (Faris: OECD, 1989). 
would be very short-lived. The Japanese government has played a very lowkey role in joining other industrial countries in criticizing the Chinese government, and the hold was officially implemented because of concern that the turmoil in China would disrupt the ability to handle incoming foreign aid monies. This approach left the Japanese government free to resume foreign aid quickly, and even by the end of the summer of 1989, the government appeared to be ready to do so. Although the government position on the China problem was couched in terms of the delicate and special relationship between Japan and China stemming from the atrocities of the war, it also opened the way for Japan to play an even larger role in China's external financial ties by returning relations to normal in advance of other industrial nations.

The picture in Indochina is different. Burma, Cambodia, Vietnam, and Laos all receive some ODA from the world, but neither Japan nor the United States is heavily involved (except for Japan's provision of $\$ 172$ million to Burma in 1987). The multilateral aid agencies and certain European nations play a much larger role here. Should the conflict in Indochina come to an end, though, the way would be opened for much larger aid flows. Devastated by decades of war and inefficient economic management, these nations are prime candidates for increased foreign aid efforts, and Japan, at least, would be in a position to provide much larger sums of money. Japan has remained cautious to date, apparently not desiring to move much beyond American policy, especially in the case of Vietnam.

Japanese aid used to be criticized for having a high tied ratio and for being excessively motivated by Japanese commercial interests. Although the share of untied aid in Japan's aid mix has increased, it continues to have an unusually low grant ratio and the complaints of commercial motivation 
continue unabated. The OECD puts Japan's grant element (the share of ODA disbursed as grants rather than as loans) at only 62 percent in 1986-1987, compared to an 87 percent DAC average and 97 percent for the United States. The grant element for Japan actually declined from 75 percent at the beginning of the $1980 \mathrm{~s}^{5}$ Even untied aid from Japan is often structured in such a way (as through tied engineering studies) that Japanese manufacturers end up with the contracts. This bias is even true of multilateral loans from the Asian Development Bank, and American officials involved with the Bank have been complaining for at least the past decade that their Japanese counterparts do all they can to steer contracts for ADB-financed projects to Japanese corporations. 6

Japan also continues to be plagued with a woefully inadequate bureaucratic infrastructure. The two principal Japanese aid agencies--the Japan International Cooperation Agency (JICA) and the Overseas Economic Cooperation Fund (OECF) are seriously understaffed and have very limited capabilities to monitor field work. Partly because of the understaffing, the Japanese government continues its policy of providing aid only on a request basis; it responds only to project proposals submitted by recipient countries rather than using its own people to design an agenda of projects. This policy reinforces the tendency for a commercial bias in aid because Japanese trading companies operating in these countries often become the leaders in designing projects and helping the governments of these countries

5. Ibid., p. 174 .

6. Officially, Japan and the United States have equal capital participation and equal numbers of personnel at the Asian Development Bank. By agreement, Japan has the director of the bank, which would seem to be a minor advantage. However, the sense among Americans is that the Japanese have an undue influence over bank affairs. 
deal with the Japanese aid agencies. This tendency is not at all surprising since these companies have the planning expertise that is often lacking in developing countries and have the expertise in dealing with the Japanese bureaucracy, but their interests are obviously and inextricably tied to those of the Japanese manufacturing and commercial sectors. Consider further that the principal institute in Japan designed to conduct research on developing economies is actually a subsidiary of the Ministry of International Trade and Industry (MITI). The Institute of Developing Economies is known in Japanese as Ajiken (Asian Research), which is an indication of the organization's principal research focus. The institute is a credible organization that engages in sophisticated economic research, but the fact that its research agenda is provided entirely by MITI is disquieting. MITI, one of several government ministries involved in overseeing Japanese foreign aid, promotes the interests of the Japanese manufacturing sector.

\section{Changes and Implications}

For many years Japan has been the "bad guy" in the Asia Pacific region-accused of not importing enough, not transferring technology with investment, and driving hard bargains (tied financial assistance, sales of defective equipment, etc.), with rememberance of the militarism of the 1930 s and 1940 s always strong among other Asian countries. Whether these accusations were truly justified or not, current macroeconomic changes will bring major changes in Japan's reception throughout the region. The willingness of all these countries to attend the funeral of the showa emperor in February 1989, who symbolized the wartime agony they suffered at the hands of the Japanese military, is one sign of the changes taking place. 
Rapid shifts are now occurring in all three dimensions of the economic relationships explored above. First, Japan's imports of manufactured goods have been rising rapidly since 1986 and could continue to do so for some time. Second, Japan's foreign direct investment in the region is growing somewhat more rapidly, even though that growth is considerably lower than the high and rising growth in investment destined to other regions of the world. Third, ODA continues to expand at a substantial pace, and a large portion of the bilateral segment of this aid continues to be allocated to Asian countries.

As long as the yen remains very strong and the Japanese economy continues to expand through domestic demand, these trends should continue. The rise in the yen, up 100 percent against the dollar since 1985, has provided the motivation for the increase in imports. Even a country such as Japan which can be described as protectionist (even though tariffs and quotas are no longer significant) must respond to movements in exchange rates. The landed cost of foreign products is now so much below that of domestic products in many cases that manufacturers and distributors cannot ignore them. Furthermore, broader attitudes among businesses and consumers toward the role of manufactured imports in the economy appear to be changing. Whereas government publications used to enumerate the reasons why Japan imported few manufactured goods, they are now extoling the virtues of imports (as a means of controlling inflation, increasing consumer choice, and providing competitive pressure on domestic industry). ${ }^{7}$ The distribution sector, long considered part of the problem in getting

7. See especially the Ministry of International Trade and Industry, Tsusho Hakusho [Trade White Paper], 1988 edition (Tokyo: Ministry of Finance Printing office, 1988). 
manufactured goods into the country, is now undergoing some scrutiny from the government and at least modest regulatory liberalization appears likely.

The strong appreciation of the yen has also provided a greater incentive to invest abroad. Despite the conviction that firms had concerning the virtues of keeping production centrally located at home, the disparity in costs between Japan and other countries is now causing them to change their attitudes. But even now the impact of these changes on Asia have been moderate. As shown in Table 6, Japan's cumulative direct investment in the manufacturing sector in Asia was growing at a 10.8 percent annual pace in the first half of the $1980 \mathrm{~s}$, rising to a 15.7 percent annual rate from 1985 through 1988. This acceleration was far more modest than the overall rate of direct investment growth after 1985 (25.5 percent) or the rather high growth of FDI in North America ( 43.3 percent).

Even this moderate acceleration in Japanese foreign direct investment in the rest of Asia should bring a rise in Japan's relative position. Relative to other foreign investors and relative to the local economies, Japan will become more visible. Furthermore, new investment will likely be concentrated in a very small number of Asian countries (Korea, Taiwan, Thailand and Malaysia principal among them) where the Japanese presence will be even more noticeable. Japanese investors also are more adept at tying local firms closely to themselves even though their equity ownership position may be small through retention of critical skills in Japanese staff dispatched to the local operation or through tight control over non-equity financing (bank loans and trade credit), which may make the perception of Japanese dominance far stronger than simple data on the dollar amount of investment would indicate. 


\section{Table 6}

Recent Trends in Foreign Direct Investment (millions of dollars)

$$
12 / 31 / 80 \quad 12 / 31 / 85 \quad 3 / 31 / 89 \quad \text { Growth }
$$

$\begin{array}{lrrrrr} & & & 86 / 81 & 88 / 86 \\ \text { Total } & \$ 12,179 & \$ 23,819 & \$ 49,843 & 14.4 \% & 25.5 \% \\ \text { North America } & 2,332 & 7,440 & 23,944 & 26.1 & 43.3 \\ \text { Asia } & 4,444 & 7,434 & 12,371 & 10.8 & 15.7\end{array}$

Source: Ministry of Finance, Kokusaikin'yukyoku Kin'yu Nenpo, 1986, pp. 458-459, 1981 edition, pp. 352,353; and 1982 editions and JEI Report, No. $31 \mathrm{~A}$, August 11, 1989 . 
Other indicators show a strong increase in Japanese attention directed toward Asia. The Japanese business media have been emphasizing Asia much more over the past two years, and one could term 1987 the year of the discovery of the Asian NICs and 1988 the discovery of ASEAN by the Japanese press. With an upbeat assessment of the region, the media are promoting the idea that these countries are capable of producing goods of sufficient quality for the Japanese market, thereby endorsing the idea of increased direct investment. ${ }^{8}$ Therefore, Japanese firms are seeing Asia as a base for production of goods destined for consumption in Japan (rather than for local or third markets as in the past). Data from a recent MITI survey indicates that the portion of output from Japanese-owned factories in Asia shipped to Japan has risen from 9.8 percent in 1980 to 16.7 percent in 1987. This portion is considerably higher than the 9.1 percent average for all Japanese overseas investment. ${ }^{9}$

Finally, the pressures that have caused Japan's foreign aid spending to increase continue to be present. As a major economic power, the Japanese government feels the pressure to provide a greater contribution to international peace and stability. The public and government continue to believe that Japan's primary contribution to the world should be economic rather than military, although defense spending has also risen at an above average pace in the 1980s. Even though defense spending and foreign

8. As an example of this trend, see "Ajia no Seiki: Nihon no Yakuwari" [The Asian Century: Japan's Role], Toyo Keizai, November 15, 1986; or Yukiko Fukagawa, "Ajia no Dainamizumu o Torikomu Nihon: Nihon-ASEAN-NICs no Shin Sangyo Chizu" [Japan Grasping Asian Dynamism: The New Industrial Map of Japan/ASEAN/NICs], Ekonomisuto, July 4, 1988.

9. Kenji Takeuchi, "Effects of Japanese Direct Foreign Investment on Japan's Imports of Manufactures from Developing Economies," unpublished paper, World Bank, 1989. 
economic aid are by not means entirely substitutable commodities, there is some tendency to view them as such in Japan. Note, however, that in much of the discussion of these issues in Japan, the main motivation is one of obligation to the other industrial nations. By spending more on foreign aid, the Japanese government appears more intent upon impressing the United States and the European countries that it is doing more to carry the "burden" of international security than upon actually contributing to world development. Whatever the motive, though, Japanese aid will continue to grow at an above average rate.

As it grows, Japanese foreign aid continues a close association with industry. Keidanren, for example, established a new organization, the Japan International Development Organization, Ltd. (JAIDO) in the spring of 1989 to promote direct investment in developing countries. This organization is one-third funded by the OECF--the government's soft loan agency mentioned above. Keidanren has also established an internal group, the Committee on International Cooperation Projects (CICP) to oversee and approve JAIDO investments. 10 In essence, JAIDO and CICP provide a vehicle to gain concessionary financing for Japanese commercial direct investment in Asian countries. American officials are also concerned that this will become a means for Japan to gain more influence over the Asian Development Bank, as JAIDO begins to request co-financing for its investments. JAIDO may be a useful tool in promoting beneficial investment and economic development in Asia, but it provides an explicit combination of government and business to promote Japanese economic benefit which runs counter to much of U.S. foreign 
aid philosophy and will raise serious concerns among American officials as furthering a mercantilist Japanese policy stance.

Over the next several years, the United States could easily follow the opposite trend. Recognition that the federal budget deficit is a major economic problem for the United States is now quite widespread, although progress in reducing the deficit remains limited. The progress in achieving this goal could be somewhat limited over the next several years, but the direction of change will be downward and not upward. By taking some of the pressure off capital markets, and thereby reducing the net inflow of capital from the rest of the world, this scenario leads to a smaller U.S. merchandise trade and current-account deficit (brought about by a continued weak dollar and by slower growth of consumer demand).

A reduction of the U.S. global deficit must affect trade with Asia. These countries will find the United States a less vibrant market for their exports, and will find themselves under more pressure from the United States to dismantle their own import barriers in order to facilitate absorption of swelling exports from the United States. These developments could also affect American direct investment in Asia. To date, however, there is little evidence of a slowdown in the pace of American direct investment in manufacturing in Asia. From 1985 to 1987, American cumulative FDI in manufacturing in Asia and the Pacific other than Japan grew at a 20 percent annual rate. 11 Nevertheless, the depreciation of the dollar ought to bring

11. U.S. Department of Commerce, Bureau of Economic Analysis, Survey of Current Business, August 1988, pp. 47-52. U.S. data are not compatible with Japanese data cited earlier because the United States measures the current value of local investments (including reinvested earnings and local capital sources), whereas Japan measures only the cumulative flow of investment funds from Japan. 
some reconsideration of new overseas investment when those investments are motivated by cost savings. 12

With these economic developments in Japan and the United States comes a substantial role reversal in the region: Japan's image will improve while that of the United States will worsen. Japan will be the growing market for Asian manufactured exports while the United States is not; Japan will become a source of a rising amount of direct investment (which may be quite welcome if it generates exports back to Japan) while American firms may slow their investment; budget cutting in Washington may bring further reductions in the already small U.S. foreign aid budget, while Japan's continues to grow. Meanwhile, the antagonism that remains as a legacy of the second World War will further diminish as generational transition continues (including the death of the Showa emperor, eliminating a symbol of Asian distrust of Japan). The Japanese are, for example, touting the idea that the United States has eliminated GSP treatment for the Asian NICs while Japan has not. Prime Minister Takeshita also made a point of presenting issues of concern to Asian countries at the 1989 industrial-nation summit meeting, another symbolic gesture representing a unilateral assumption of a role as Asian spokesman. The intent appears to have been to impress Asian countries that Japan is different from other industrial nations demonstrating its interest and concern for the interests of regional nations at this meeting.

Implications for Japan's Role in Regional Cooperation

12. Some caution is in order here, since dollar appreciation in the first half of the 1980 s did not bring any acceleration of outward foreign direct investment by U.S. firms. U.S. Department of Commerce, International Trade Administration, International Direct Investment: Global Trends and the U.S. Role, 1988 Edition (Washington: U.S. Government Printing Office, 1988), p. 20. 


\section{$-17-$}

Japan has been a rather insular nation over the postwar period, willing to export to the world but unwilling to play much of an active role in any other way. Now Japan is inevitably drawn into a more active role by its ownership of overseas assets and provision of ODA. Furthermore, Japan exhibits much greater interest in the Asia-Pacific region after years of largely ignoring its Asian neighbors. Given the general rise of economic ties within the region over time, some form of closer cooperative arrangements makes sense.

To the extent that Japan's outreach to the region promotes economic development, the recent changes are entirely to be welcomed. However, there is room for concern about the nature of Japan's interaction with the region because the newfound interest may drift toward a regionalism that seeks to exclude the United States and other industrial countries. Despite the fact that little of the official rhetoric makes specific statements to this effect, the possibility of such a development must be recognized. What the Japanese see as so encouraging about the rest of Asia (and especially the four NICs plus Thailand) are similarities to Japan's own economic development in the past. That is, the focus is on aspects of these economies and cultures which provide a link to Japan, and not to the West or the United States. Even the spread of offices of Japanese department and super stores through Asia has been described as part of this process (in an article envisioning a large Japanese-run regional distribution network throughout Asia in the not-too-distant future. Because they maintain both buying operations and sales outlets, Japanese firms are described as having superior information-gathering ability and "greater trustworthiness" compared to American or European distributors, who have operated purchasing 
offices in these countries for years. ${ }^{13}$ Others have referred to Asia as a large high-quality market in which Japanese firms will plan their

procurement from the "most appropriate" production base." 14

The key element in these and other commentaries on Asia is the sense of exclusivity. The United States or other industrial nations are rarely mentioned, or if they are, it is in a negative context. An aggressive tone has emerged in some articles, in which the Japanese portray the United States as being unfair to the rest of Asia, in explicit or implicit comparison to a more benevolent Japan. Consider, for example the title of a recent cover story in a major Japanese business publication: "No More Japans! Japan and the U.S. Policy of Beating Up South Korea and Taiwan."15 Some Japanese have gone so far as to see evolving regionalism in the Western Pacific proceeding as far as it has in Europe, driven by both the high yen and the continuing economic development of other countries in Asia. In a recent roundtable discussion, one participant surmised that "Japan and other Asian countries will increasingly draw away from the United States, " a trend viewed with favor because Asia has been "overly dependent" on the

13. "Yu'nyu Daikyosui II: Kaihatsu Yu'nyu ga Kasoku Suru Hyakkaten-Supa no Ajia Ryutsuken" [The Big Flood of Imports II: The Asian Sphere of the Department Stores and Super Stores' Accelerating Development Imports], Toyo Keizai, July 4, 1987, p. 14.

14. Yukiko Fukugawa, "Ajia no Dainamizumu o Torikomu Nihon," pp. 86-89.

15. "No Moa Japan! Beikoku no Kankoku-Taiwan Tataki to Nihon", Toyo Keizai, July 18, 1987, pp. 4-17. The article is actually somewhat more innocuous than the sensational title, dealing with the decision of USTR to keep South Korea and Taiwan from becoming trade problems on the order of Japan by making them open up their markets earlier. But the tone of the title and much of the writing is one of American fear of having more successful industrialized countries across the Pacific. 
United States."16 A long-term economic forecast to the year 2000 issued by the Research Institute on the National Economy (a respected private group) adopts a similar position, predicting that the continued rapid growth and development of the Asian NICs will make closer ties between them and Japan more likely. This report anticipates a greater horizontal division of industry and a rise of intra-industry trade, bringing about a de facto yen bloc as the portion of regional trade denominated in yen rises naturally. 17 More conservative organizations avoid endorsing any exclusive regional grouping, but point out the same trends in trade and investment that imply much closer ties between Japan and the rest of Asia. For example, a recent report from an advisory committee to MITI with a heavy representation of "internationalists" foresees a new posture for Japan toward Asia, and makes a major point of Japan's continued GSP treatment for the Asian NICs. This same report speaks of Japan becoming a major market for the exports of these countries, although it generally casts its discussion in a multilateral framework that explicitly includes the United States. The report endorses initiatives such as JAIDO by stressing that Japan's Asia policy should be a coherent package which will draw Japan and Asian economies closer together. The elements of this coordinated package are to include importing more from

16. Roundtable discussion with Toshio Watanabe, Naoki Tanaka, and Masao Okonogi, "Kankoku ga Senshin Koku ni Naru Hi" [The Day South Korea Becomes an Advanced Country], Ekonomisuto Rinji Zokan, November 2, 1988. The remarks are from Professor Watanabe, a specialist on Asian economic development.

17. Kokumin Keizai Kenkyukai [Research Institute on the National Economy is the official English rendition of the Institute's name], Choki Keizai Yosoku: 2000-Nen no Nihon Keizai, Higashi Ajia Koiki Keizaiken no Kannosei [Long-Term Economic Forecast: The Japanese Economy in the Year 2000--The Possibility of a Broad Economic Area in East Asia] (Tokyo: Kokumin Keizai Kenkyukai, August 1988), especially pp. 9-15. 
Asia, using foreign direct investment to bring about industrial specialization, implementation of an expanded medium-term foreign aid program, cooperation on energy policy, and increased regional dialogue. The report stresses strongly the granting of foreign aid to specifically service Japan's private-sector investment activities in developing countries. 18

As might be expected from such discussion in Japan, some debate has been occurring in Japan over new institutional arrangements for the Asia Pacific region. Officially the Japanese government stands in favor of integrating the Asian NICs into the OECD, a position that should be applauded. At the same time, however, the Japanese government is pursuing creation of a new regional organization. A report on this topic by an advisory commission to MITI released in June 1989 supported the Australian call for ministeriallevel meetings of Asia-Pacific nations to discuss economic development and cooperation issues. This report also specifically speaks of "outward'looking" regional cooperation, and specifically includes the United States, Australia, and New Zealand. But it also indirectly promotes several MITI initiatives (such as JAIDO and a coordinated regional energy policy which would be dominated by Japanese firms). Other suggestions, including environmental protection belong in a global framework (or at least one which transcends the boundaries of the Asia-Pacific region) rather than a regional one. 19

18. Ministry of International Trade and Industry, Nihon no Sentaku: Nyu Gurobarizumu e no Kokan to 'Shin Sangyo Bunka Kokka' no Sentaku [Japan's Choices: Choices Concerning Contribution to the New Globalism and the New National Industrial Culture] (Tokyo: Tsusho Chosakai, 1988), pp. $46-47,50-53$.

19. Report of the Council for the Promotion of Asian-Pacific Cooperation: Toward an Era of Development Through Outward-Looking Cooperation (Summary), June 1989. See also Japan Times weekly Overseas Edition, 
A number of academics and government officials are also very interested in the concept of a free trade zone, either bilaterally with the United States or regionally. In some sense this concept goes back as far as the late 1960 s when the Japanese proposed a Pacific Free Trade Area. 20 At the present time, the Japanese claim their motivation is due to a perception that the United States is moving away from a multilateral approach to trade, as evidenced by the U.S.-Canada agreement. They also note the statements by former Ambassador Mike Mansfield and various members of Congress in favor of a bilateral free trade arrangement with Japan. However, their interest appears to go beyond a simple reaction to an American position.

The concept of a bilateral free trade zone with Japan or other Asian countries has very little support in Washington. Virtually no U.S. government officials at all familiar with Japan are in favor of such an arrangement, for a variety of reasons. Discussion of a regional arrangement is not likely to proceed very far either. The basic problem lies in the perception that trade barriers in Japan are not easily addressed in a free trade agreement, so that such a move would not provide much increased access to Japanese markets. Furthermore, a bilateral deal with any single country

Continued from previous page April 8, 1989. The genesis of the proposal was to provide Prime Minister Takeshita a "present" to take to ASEAN on a state visit in late April, but the report was not issued until after his demise as prime minister.

20. Harry Harding and Edward Lincoln, "The East Asian Laboratory, " in John D. Steinbruner, ed., Restructuring American Foreign Policy (Washington: The Brookings Institution, 1989)j, p. 193. 
or a limited group of Asian nations would be extremely poor diplomacy, raising immediate protests or demands for similar treatment from the rest. 21 There is a scenario, however, in which a regional trade arrangement could emerge regardless of American government opinion. If the European nations were to become somewhat more protectionist toward the rest of the world after 1992, and if the United States spurns the idea of a bilateral or regional trade arrangement with Japan or Asia, the rising trade and investment ties between Japan and Asia, as well as the increased interest of the Japanese in their Asian connection could well lead to consideration of an Asian preferential trade zone exclusive of the United States. Other Asian nations would likely oppose such a move, but given rising exports to Japan (compared to stagnant sales to the United States), pressure from the United States to open their markets, rising FDI from Japan, rising ODA from Japan, and other inducements, their acquiescence is possible in the 1990s.

\section{Policy Implications}

The scenario just sketched is a troubling one. An Asian economic zone centered on Japan would not be to the long-term interest of the United States and it might be destabilizing to the region as well. Asian countries might go along with initiatives from Japan, but the exclusivity that would accompany such an arrangement would bring considerable tensions. In addition, American commitment to a substantial military presence in the region would be severely damaged by any economic development which seeks to exclude the United States. A diminished American military presence would be

21. For a review of these and other arguments both for and against a free trade area with Japan or other Asian countries, see the International Trade Commissions recent survey of pros and cons on a free trade area with Japan and with other Asian nations. 


\section{$-23-$}

a further destabilizing development especially in the presence of an increasingly dominant economic Japan.

This scenario remains relatively unlikely. However, the following proposals would make it less likely and would help to move the region in the direction of a more productive cooperation:

1. Japan should dramatically increase its training of specialists on the region. A stronger core of people in Japan who can speak to the needs and problems of Asian developing countries would improve the quality of Japanese foreign aid, act to counter the heavily commercial orientation of aid and other aspects of Japanese foreign policy toward the region, and would provide a more human dimension to Japan's interaction with Asian countries. A major expansion of university area studies programs, including greater opportunities to study or travel abroad, should be the key element in this development. In addition, however, Japan could use a strong effort by the government to create something akin to the American Peace Corps of the 1960s. Japan has an equivalent to the Peace Corps, but the missing element is any visibility or any evidence of substantial interest among the Japanese in working for such an organization. Service abroad, and especially in Asia, should be elevated to a more acceptable position. The point is not effectiveness (as many see the U.S. Peace Corps as ineffective in the 1960s), but to generate international experience, understanding, and interest among the Japanese.

2. Japan should also continue its macroeconomic adjustment, expanding domestic demand as part of a program to both benefit the Japanese public and to reduce the trade surplus by absorbing more imports. This process must enable foreign firms to get a real chance to sell more to Japan; if increased imports come primarily from the overseas subsidiaries of Japanese 
firms, domestic demand expansion will have failed to bring about real change in Japan's position in the world. Conversely, the United States must also continue its macroeconomic adjustment. Admitting the dilemmas this poses for the American image in Asia, the need for reduction or elimination of the trade and current-account deficit is overwhelming.

3. Japan should stick to a multilateral framework in dealing with the rest of the Asia-Pacific region. Moves such as promoting the NICs seminar in the OECD in the spring of 1988 should be continued; discussion of bilateral or regional trade blocs should be discouraged. This is an area where the Japanese government could easily take a strong initiative, clarifying its commitment to the GATT and the Uruguay round, disassociating itself from notions of bilateral or regional preferential trade schemes, and ending government-sponsored research on these ideas. There is no harm in the periodic ministerial conference proposed by Australia's Prime Minister Hawke (and strongly supported by the Japanese), but many issues which the Japanese envision discussing--trade, environment, promotion of foreign direct investment--are more appropriate in non-regional settings.

4. The United States should also do all it can to encourage Japan to move in a more liberal, less mercantilist direction toward the rest of the Asia-Pacific region. Greater communication on issues of mutual interest where Japan can play a beneficial and useful role are important in order to ensure that Japanese policy toward the region evolves in a manner that is advantageous to all and not just for Japanese corporations. The United States must also maintain a presence in Asian matters. Foreign aid should be increased and Japanese efforts to gain greater control over the Asian Development Bank should be resisted. If the United States plays a more 
limited role in Asia in the future, Asian countries would have little choice but to accept Japanese policy initiatives.

These four points do not represent any innovation or major change in policy. The GATT, United Nations, IMF, World Bank, and other institutions were created in the early postwar era out of a belief that regionalism was not desirable as a general principle. The reasons for opposing preferential regional arrangements are as strong today as 40 years ago. The informal organizations that now provide an overlapping set of fora in which businessmen, academics, and government officials of Asian-Pacific countries can interact are all positive steps; as we have moved toward greater economic integration, the need for enhanced communications and information exchange has become stronger. However, any stronger formal institutional framework is not advisable, especially if it includes any form of preferential trade. This would be true even if the United States were a participant in a regional scheme, and is even more true if such an arrangement were centered on Japan without the United States. 


\section{Table 6}

Recent Trends in Foreign Direct Investment (millions of dollars)

$12 / 31 / 80 \quad 12 / 31 / 85 \quad 3 / 31 / 89 \quad$ Growth

$\begin{array}{lrrrrr}\text { Total } & \$ 12,179 & \$ 23,819 & \$ 49,843 & 86 / 81 & 88 / 86 \\ \text { North America } & 2,332 & 7,440 & 23,944 & 26.1 & 43.3 \\ \text { Asia } & 4,444 & 7,434 & 12,371 & 10.8 & 15.7\end{array}$

Source: Ministry of Finance, Kokusaikin'yukyoku Kin'yu Nenpo, 1986, pp. 458-459, 1981 edition, pp. 352,353; 3 and JEI Report, No.
31 , August 11, 1989. 